The Orthomyaria consist of a single complex, Libelluloidea, with the single order Odonata.

Thus the whole of the Pterygote orders is subdivided into four complexes, all of which are fairly natural. Except for the positions of the Coleoptera and Hymenoptera, the subdivision corresponds with that proposed under different names by Martynov ${ }^{3}$, though his criteria of elassification differ widely from those given in the foregoing.

Besides this, the Pterygote orders may be classified under three series shown by the horizontal division of the chart. To the Inferiores belong those orders which show general morphological primitivism, middle- and large-sized body, mostly small numbers of species (excluding Orthoptera) and paucity of biological types (excluding Neuroptera). The Uniformes combine general primitiveness with some narrow specializations (mouth parts of parasites, asymmetrical head and mouth parts of thrips, silk glands of Embioptera). Minute body size, paucity of species and biological types and a strong tendency to apterism are also typical of the series. The Superiores consist of five orders which on account of their maximum morphological specialization, enormous numbers of species and biological types and the widest variability of body size should be regarded as undoubted peaks of insect evolution.

The interrelations of the horizontal and vertical divisions of the chart make it clear that, in each of the three main complexes (Panorpoidea, Hemipteroidea, Orthopteroidea), evolution follows the same course; namely, starting with primitive groups like Mecoptera, Psocoptera or Blattoptera, it leads to the maximum abundance of the forms of life in the progressive orders of Superiores on one hand and to the narrow specialization of the Uniformes on the other. Thus a definite structure is typical of each complex.

The system described is on one hand based on the types of wing mechanism, mouth parts and metamorphosis; on the other, it attempts to take into account the general 'height' of organization, and thus make a distinction between primitive, regressive and progressive orders of Pterygote insects.

"Weber, H., "Grundriss der Insektenkunde" (1938).

"Snodgrass, R. E., "Principles of Insect Morphology" (1935).

3 Martynov, A. V., "In Filipjev's Opredelitel nasekomykh" (1928).

4 Martynov, A. V., "Etudes sur l'histoire geologique et de phylogenie des ordres des Insectes (Pterygota) I. Palaeoptera et NeopteraPolyneoptera". Travaux Inst. Paleont., Acad. Sci. USSR., (1938).

s Weber, H., "Lehrbuch der Entomologie" (1933).

- Berlese, A. G., "Insetti", 2 (1925).

\section{GEOLOGY IN THE WAR AND AFTER}

$\mathrm{D}^{\mathrm{R}}$ R. E. B. BAILEY, in a lecture to the Royal Philosophical Society of Glasgow, delivered on November 17, on "Geology in the War and After", dealt in particular with the work of the Geological Survey of Great Britain, of which he is director. The main war aim has been to give useful advice on : (1) home mineral resources, so as to meet essential needs with economy of shipping and foreign currency ; (2) underground water, for new aerodromes, camps and factories; (3) subterranean facilities, for storage and personnel. Coal is the main mineral asset of Great Britain. Two interesting current problems occupy a considerable share of the Geological Survey's time : first, the resurrection, with modern equipment, of coal outcrop working, and second, the correlation of coal seams. Correlation work has been intensified because confused nomenclature impedes progress that may be expected from the recent unification of ownership in the hands of the State. In its coal work, the Geological Survey co-operates elosely with another branch of the Department of Scientific and Industrial Research, namely, the Fuel Research Board, the concern of which is with the quality of the coal seams.

Iron comes second only to coal in importance. Iron ore at present is mostly won from bedded ores in the English Midlands, exploited, as in the case of coal crops, with mechanical diggers. The Survey has done much to help in this wide field. Elsewhere it has directed attention to valuable veins of low-phosphorus iron-ore and has guided their successful development. In regard to non-ferrous metals, the Survey has had successes, but perhaps it is wiser not to particularize. Among non-metallic vein minerals, special attention may be directed to fluor. The Survey warned the steel industry of a possible fluor shortage, and played its part in averting trouble. One important step was to interpret the shape of a particular fluor body, which allowed of ordered replanning of mining operations. In this matter Canadian miners, now sappèrs, helped greatly by teaching British comrades a novel technique. Felspar may be mentioned here, as a mineral in which, through Survey advice, Great Britain has passed from zero production to selfsufficiency, even in the most exacting grades required for dentures.

Sand and gravel are, of course, always in demand. The year 1939-40 was 'sand-bag year' for London. The coming of war called for rapid reinforcement of existing buildings, and the Survey indicated the particular parks and open spaces where sand-bags could be filled. The Civil Defence authorities have estimated the resultant saving at $\$ 125,000$. Moreover, external roads and railways were freed for other traffic. Sand of suitable quality for the manufacture of optical glass had been located by the Survey so long ago as 1921, and its significance constantly stressed in the proper quarter during ensuing years. The reward came in 1940, when all Continental sources of this strategic mineral passed into enemy hands. Mica, essential in electrical apparatus, has also been found, of good quality and useful amount.

The importance of the Survey's store of digested information in regard to underground water and underground possibilities of excavation is self. evident. Many inquiries also have been answered upon matters of overseas geology. As a rule, the information has been supplied from the Library; but one member of staff has the privilege of serving as geological adviser in the Central Mediterranean Force, and another was able to visit Malta last spring.

In conclusion, Dr. Bailey expressed the hope that geology would play as useful a part in reconstruction as in war, and that geologists would remember in the future, as in the past, that man does not live by bread alone ; in other words, once victory has brought the present emergency to a close, geologists will return to wrestle with the rocks to win from them treasures, intellectual as well as material. It is of happy augury that a geologist, Prof. A. E. Trueman of the University of Glasgow, has been appointed to the small committee that leaves for West Africa in the New Year entrusted with a mission that depends for success upon a combination of good-will, good sense and technical knowledge. 